\title{
The effect of erythropoietin on serum uric acid levels during renal ischemia reperfusion injury in rats
}

\author{
Constantinos Tsompos ${ }^{1}$, Constantinos Panoulis², Konstantinos Toutouzas ${ }^{3}$, George Zografos ${ }^{3}$, Apostolos Papalois ${ }^{4}$
}

${ }^{1}$ Department of Obstetrics and Gynecology,

Mesologi County Hospital,

Etoloakarnania, Greece

${ }^{2}$ Department of Obstetrics and Gynecology,

Aretaieio Hospital,

Athens University,

Attiki, Greece

${ }^{3}$ Department of Surgery, Ippokrateio Hospital,

Athens University,

Attiki, Greece

${ }^{4}$ Elpen Pharmaceuticals S.a. Co. Inc., Pikermi,

Attiki, Greece

Submitted:

20.09.2013

Accepted:

20.01.2014

\section{Correspondence:}

Constantinos Tsompos, MD,

Department of Obstetrics and

Gynecology,

Mesologi County Hospital,

Etoloakarnania, Greece

Phone: 00302106107867

E-mail:

constantinostsompos@yahoo.com

(C) Copyright 2014 by Turkish

Association of Urology

Available online at

www.turkishjournalofurology.com

\begin{abstract}
Objective: The aim of this experimental study was to assess the effect of erythropoietin on a rat model, particularly under a renal ischemia reperfusion protocol. The beneficial or lack of effects of that molecule on the excreted renal product of serum uric acid were studied biochemically.

Material and methods: Forty rats were used with a mean weight of 247.7 gr. Serum uric acid levels were measured measured at 60 min after reperfusion (Groups A and C) and at 120 min after reperfusion (groups $\mathrm{B}$ and $\mathrm{D})$

Results: 1) Erythropoietin administration non-significantly decreased the serum uric acid levels non-significantly by $0.02 \mathrm{mg} / \mathrm{dL}[-0.2415423 \mathrm{mg} / \mathrm{dL}-0.2015423 \mathrm{mg} / \mathrm{dL}](\mathrm{p}=0.8560)$, in accordance with the paired t-test $(\mathrm{p}=0.8438)$. Reperfusion time non-significantly increased the serum uric acid levels non-significantly by 0.17 $\mathrm{mg} / \mathrm{dL}[-0.0444933 \mathrm{mg} / \mathrm{dL}-0.3844933 \mathrm{mg} / \mathrm{dL}](\mathrm{p}=0.1169)$, in accordance with the paired t-test $(\mathrm{p}=0.1648) .3)$ The interaction of erythropoietin administration and reperfusion time non-significantly increased the serum uric acid levels non-significantly by $0.1 \mathrm{mg} / \mathrm{dL}$ [-0.0295564 mg/dL-0.2295564 mg/dL] (p=0.1264).
\end{abstract}

Conclusion: Erythropoietin administration, reperfusion time and their interaction have no significant shortterm alterations on serum uric acid levels. Conclusions cannot be extracted by non-significant p-values within 2 hours. Obviously, longer study times may permit safer results.

Key words: Erythropoietin; ischemia; kidneys; reperfusion; uric acid.

\section{Introduction}

Tissue ischemia and reperfusion (IR) remains one of the main causes of permanent or transient damage, with serious implications on the surrounding organs and certainly on patients' health. However, even if important pharmaceutical progress has been made in the management of these damages, the use of erythropoietin (Epo) still raises fundamental questions. Which is the action velocity of Epo? How short-term of an action prospect does this molecule have on the tissue or organ of interest? When should Epo be administeredthat is, how soon after the damage? Which is the optimal and most effective dosage? This study has been motivated by numerous studies $^{[1]}$ that have attempted to demonstrate the probable protective effect of Epo in various ischemic tissues in short term usage. All studies used a characteristic substance tissue as the functional index of IR. The dose ${ }^{[2]}$ of the molecule of Epo was $5,000 \mathrm{IU} / \mathrm{kg}$. The aim of the present experimental study was the trial of Epo on a rat animal model and in a renal IR protocol. The benefit or lack thereof of this molecule was studied by measuring the renal excreted product of serum uric acid (SUA). Renal IR injury results from a generalized or localized impairment of oxygen and nutrient delivery to, and waste product removal from, the cells of the kidney. There is a mismatch between the local tissue oxygen supply and the demand and accumulation of the waste products of metabolism, such as uric acid. Because of this imbalance, the tubular epithelial cells undergo injury; if the injury is severe, death by apoptosis and necrosis (acute tubular necrosis) occur, with the organ functional impairment of water and electrolyte homeostasis and reduced excretion of the waste products of the metabolism. Reduced excretion signals the increased presence of these waste products in the serum. Thus, the fluctuations in the measurement of the serum levels of these waste products indirectly reflect what happens at the renal tubules. 
The potential for Epo to influence the renal tubules' functions is investigated by SUA measurement.

\section{Material and methods}

This experimental study was approved by the scientific committee of Ippokrateion General Hospital, Athens University, and by Veterinary Address of the East Attiki Prefecture. The procedure was laid out by the Exprerimental Research Center of ELPEN Pharmaceuticals Co. Inc. S.A. at Pikermi, Attiki. All of the materials, including consumables, equipment and substances used, were courtesy of S. A. Wistar albino rats spent 7 days in the laboratory before experimentation with easy access to water and food. They were randomly assigned into the following experimental groups, with10 animals in each group, for the period of acute experimentation (that is, after the experiment, animal expiration was ensured upon awakening, and none survived):

1) Ischemia for $45 \mathrm{~min}$ followed by reperfusion for $60 \mathrm{~min}$ (Group A).

2) Ischemia for $45 \mathrm{~min}$ followed by reperfusion for $120 \mathrm{~min}$ (Group B).

3) Ischemia for 45 min followed by immediate Epo intravenous (IV) administration and reperfusion for 60 min (Group C).

4) Ischemia for 45 min followed by immediate Epo IV administration and reperfusion for $120 \mathrm{~min}$ (Group D).

The selected preparation was Epoetin- $\alpha$, which is human Epo produced using recombinant DNA technology. This preparation stimulates erythropoiesis and is used to treat anemia, which is commonly associated with chronic renal failure and cancer chemotherapy. Its dosing is controversial, and higher doses are associated with side effects. The experiment was begun by prenarcosis and the animals were submitted into general anesthesia in the animals. Their electrocardiograms and acidometry were continuously monitored, in compliance with internationally accepted guidelines, including the Helsinki Declaration and the guidelines for Good Clinical Practice and Good Laboratory Practice. The inferior aorta was prepared so as its blood supply could be excluded by forceps. After exclusion, the protocol of IR was applied, as described further in the experimental groups. The molecules were administered at the time of reperfusion through the inferior vena cava catheterization, which had been carried out after general anesthesia. The SUA measurement was performed at the 60 min time point of reperfusion for Groups $A$ and $C$ and at the $120 \mathrm{~min}$ time point of reperfusion for Groups B and D.

SUA is considered to be a reliable index substance of the renal excretory system with great clinical diagnostic value concerning general metabolism and renal function. Additionally, rat weights could potentially represent a confusing factor, e.g., fatter rats would have higher SUA levels. This suspicion will be investigated, will hopefully not be proved, and then will be rejected. Rats were subjected to general anesthesia by initial intramuscular (IM) administration of $0.5 \mathrm{cc}$ of a compound, constituted by $0.25 \mathrm{cc}$ xylazine, [25 cc, $20 \mathrm{mg} / \mathrm{cc}$ ] and $0.25 \mathrm{cc}$ ketamine hydrochloride [1000, $100 \mathrm{mg} / \mathrm{cc}, 10 \mathrm{cc}]$. Next, 0.03 cc butorphanol [10 mg/cc, $10 \mathrm{cc}$ ] was administered subcutaneously (SC) before laparotomy to eliminate pain. A continuous oxygen supply was applied during the performance of the entire experiment. Ischemia was caused by clamping the inferior aorta for $45 \mathrm{~min}$ after laparotomic access. Reperfusion was achieved by removing the clamps and re-establishing inferior aorta patency. Overall, 40 female Wistar albino rats of mean weight 247.7 gr [SD \pm : $34.99172 \mathrm{gr}$ ] were used, with a min weight $\geq 165$ gr and a max weight $<320$ gr.

Twenty control rats of mean weight 252.5 gr [SD \pm : 39.31988 gr] were subjected to ischemia for $45 \mathrm{~min}$, followed by reperfusion. These rats were assigned into the groups A or B. Group A included 10 controls rats of mean weight 243 gr [SD \pm : $45.77724 \mathrm{gr}$ ] and mean SUA $1.03 \mathrm{mg} / \mathrm{dL}$ [SD $\pm 0.1766981 \mathrm{mg} / \mathrm{dL}$ ] whose reperfusion lasted $60 \mathrm{~min}$ (Table 1 ). Group B included 10 con-

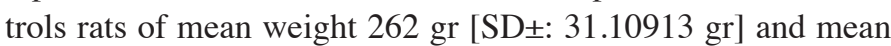

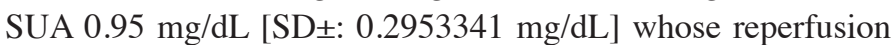
lasted $120 \mathrm{~min}$ (Table 1).

Twenty Epo rats of mean weight 242.9 gr [SD \pm : 30.3105 gr] were subjected to ischemia for $45 \mathrm{~min}$, followed by reperfusion, at the beginning of which $10 \mathrm{mg}$ Epo/ $\mathrm{kg}$ body weight were IV administered. These rats were assigned into either Group $\mathrm{C}$ or D. Group C included 10 Epo rats of mean weight 242.8 gr [SD \pm :

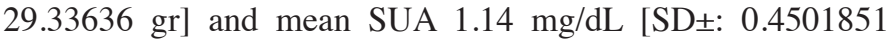
$\mathrm{mg} / \mathrm{dL}$ ] whose reperfusion lasted $60 \mathrm{~min}$ (Table 1). Group D included 10 Epo rats of mean weight 243 gr [SD士: 32.84644 gr] and mean SUA $1.18 \mathrm{mg} / \mathrm{dL}$ [SD \pm : $0.3852849 \mathrm{mg} / \mathrm{dL}]$ whose reperfusion lasted $120 \mathrm{~min}$ (Table 1 ).

Table 1. Weight and mean ( \pm SD) uric acid levels of the groups

\begin{tabular}{lccc} 
Groups & Variable & Mean & Std. Dev* \\
\hline A & Weight & $243 \mathrm{gr}$ & $45.77724 \mathrm{gr}$ \\
& Uric acid & $1.03 \mathrm{mg} / \mathrm{dL}$ & $0.1766981 \mathrm{mg} / \mathrm{dL}$ \\
\hline B & Weight & $262 \mathrm{gr}$ & $31.10913 \mathrm{gr}$ \\
& Uric acid & $0.95 \mathrm{mg} / \mathrm{dL}$ & $0.2953341 \mathrm{mg} / \mathrm{dL}$ \\
C & Weight & $242.8 \mathrm{gr}$ & $29.33636 \mathrm{gr}$ \\
& Uric acid & $1.14 \mathrm{mg} / \mathrm{dL}$ & $0.4501851 \mathrm{mg} / \mathrm{dL}$ \\
D & Weight & $243 \mathrm{gr}$ & $32.84644 \mathrm{gr}$ \\
& Uric acid & $1.18 \mathrm{mg} / \mathrm{dL}$ & $0.3852849 \mathrm{mg} / \mathrm{dL}$ \\
*standard deviation & & \\
\hline
\end{tabular}




\section{Statistical analysis}

Weight comparisons of each rat group were initially performed with every group from the 3 remaining ones, applying the statistical paired t-test (Table 2). Any emerging significant difference among the mean SUA values was investigated as to its role in the above mentioned probable significant weight correlations. Also, SUA comparisons were performed by applying a statistical paired t-test, of every SUA group with each of 3 other groups (Table 2). Furthermore, generalized linear models (glm) were applied with dependent variable set the SUA level and independent variables, the Epo administration or lack thereof, the reperfusion time, and the interaction of the two. Inserting the rats' weights as independent variables at glm, a non-significant relationship resulted with the SUA levels ( $\mathrm{p}=0.0884)$; therefore, no further investigation was needed.

\section{Results}

Concerning the SUA levels, we found the following results. 1) Epo administration non-significantly decreased the SUA levels by $0.02 \mathrm{mg} / \mathrm{dL}$ [-0.2415423 mg/dL-0.2015423 mg/dL]

Table 2. Statistical significance of the differences in

mean values for the groups after statistical paired-t test application

\begin{tabular}{lccc} 
DG $^{+}$ & Variable & Difference & p value \\
A-B & Weight & $-19 \mathrm{gr}$ & 0.2423 \\
& Uric acid & $0.08 \mathrm{mg} / \mathrm{dL}$ & 0.5120 \\
\multirow{2}{*}{ A-C } & Weight & $0.2 \mathrm{gr}$ & 0.9900 \\
& Uric acid & $-0.11 \mathrm{mg} / \mathrm{dL}$ & 0.5022 \\
A-D & Weight & $0 \mathrm{gr}$ & 1.0000 \\
& Uric acid & $-0.15 \mathrm{mg} / \mathrm{dL}$ & 0.2410 \\
B-C & Weight & $19.2 \mathrm{gr}$ & 0.2598 \\
& Uric acid & $-0.19 \mathrm{mg} / \mathrm{dL}$ & 0.1763 \\
B-D & Weight & $19 \mathrm{gr}$ & 0.1011 \\
& Uric acid & $-0.23 \mathrm{mg} / \mathrm{dL}$ & 0.2366 \\
C-D & Weight & $-0.2 \mathrm{gr}$ & 0.9883 \\
& Uric acid & $-0.04 \mathrm{mg} / \mathrm{dL}$ & 0.8159 \\
+difference for groups & & \\
\hline
\end{tabular}

( $\mathrm{p}=0.8560)$, in accordance with the paired t-test $(\mathrm{p}=0.8438)$. 2) Reperfusion time non -significantly increased the SUA levels by $0.17 \mathrm{mg} / \mathrm{dL}$ [-0.0444933 $\mathrm{mg} / \mathrm{dL}-0.3844933 \mathrm{mg} / \mathrm{dL}]$ $(\mathrm{p}=0.1169)$, in accordance with the paired t-test $(\mathrm{p}=0.1648)$. 3) The interaction of Epo administration and reperfusion time non-significantly increased the SUA levels by $0.1 \mathrm{mg} / \mathrm{dL}$ [-0.0295564 mg/dL-0.2295564 mg/dL] (p=0.1264). Reviewing the above and Table 2, Table 3 sums up the increasing influence of Epo in connection with reperfusion time.

\section{Discussion}

In humans, uric acid is the final oxidation (breakdown) product of purine metabolism and is excreted in urine. Uric acid is released in hypoxic conditions and acts as a strong reducing agent (electron donors) and potent antioxidant. Over half of the antioxidant capacity of blood plasma comes from uric acid. Approximately $70 \%$ of the daily SUA disposal occurs via the kidneys, and in humans, impaired (ischemic) renal excretion leads to hyperuricemia. The question addressed in this paper is whether Epo can restore hyperuricemia due to impaired ischemic kidneys and to what extent. Many clinical situations can be used to prove how SUA influences and is influenced by ischemic cases. SUA is a potent ${ }^{[3]}$ antioxidant, the levels of which are rapidly increased after acute ischemic stroke (AIS). The mean SUA concentration in patients with AIS upon hospital arrival was $6.1 \pm 3.7 \mathrm{mg} / \mathrm{dL}$. Patients with low SUA concentrations of $\leq 4.5 \mathrm{mg} / \mathrm{dL}$ had more favorable outcomes after a month of follow-up $(p=0.004)$, marking the magnitude of the cerebral infarction. However, significantly higher clinical improvement in AIS patients was found, ${ }^{[4]}$ with high SUA levels at admission. SUA levels showed a positive correlation with clinical improvement $(\mathrm{p}=0.02)$ and acted as an independent predictor for favorable stroke outcome $(\mathrm{p}=0.04)$ in the thrombolysis group. SUA was increased ${ }^{[5]}$ on day 7 but had decreased to baseline values by day 14 in subjects who ingested $20 \mathrm{gr} /$ day of ribose. After ${ }^{[6]}$ a strenuous IR period, uric acid is taken up by the muscle, acting as the main source of plasma hypoxanthine in the blood. The secreted hypoxanthine is taken up by the liver, where most of it is converted into uric acid. Significantly increased SUA levels were found ${ }^{[7]}$ after $5 \mathrm{~min}$ of incomplete rat cerebral IR. The above nervous

Table 3. The increasing influence of erythropoietin in connection with reperfusion times

\begin{tabular}{lcccc} 
& & & \multicolumn{2}{c}{ p values } \\
Increase & $\mathbf{9 5 \%}$ c. in. $^{ \pm}$ & Reperfusion time & t-test & \multicolumn{1}{c}{ glm } \\
$0.11 \mathrm{mg} / \mathrm{dL}$ & $-0.2113029 \mathrm{mg} / \mathrm{dL}-0.431303 \mathrm{mg} / \mathrm{dL}$ & $1 \mathrm{~h}$ & 0.5022 & 0.4812 \\
$0.17 \mathrm{mg} / \mathrm{dL}$ & $-0.0444933 \mathrm{mg} / \mathrm{dL}-0.3844933 \mathrm{mg} / \mathrm{dL}$ & $1.5 \mathrm{~h}$ & 0.1648 & 0.1169 \\
$0.23 \mathrm{mg} / \mathrm{dL}$ & $-0.0925217 \mathrm{mg} / \mathrm{dL}-0.5525217 \mathrm{mg} / \mathrm{dL}$ & $2 \mathrm{~h}$ & 0.2366 \\
\hline${ }^{*}$ confidence intervals & & & 0.1514 \\
\hline
\end{tabular}


or liver cases contain opposing elements without any clear impact of ischemia on SUA levels.

Additionally, SUA is a factor influenced by Epo. Is suitable Epo administration able to reverse ischemic renal cases? Advanced stage ${ }^{[8]}$ chronic kidney disease (CKD) IV and V participants had the higher prescription rates of uric acid lowering agents and Epo-stimulating therapies in a usual care group compared to a multidisciplinary one $(\mathrm{p}=0.01)$. Elevated ${ }^{[9]}$ SUA experimentally stimulates renal vasoconstriction and Epo production, reducing uric acid clearance. SUA and the quantity of Epo were reduced ${ }^{[10]}$ by low protein diets in patients with CKD. Familial juvenile hyperuricemic ${ }^{[11]}$ nephropathy type 2 (FJHN2) is also characterized by low Epo concentrations and hyperuricemia $\left(\right.$ SUA $>6 \mathrm{mg} / \mathrm{dL}$ ). The down-regulation ${ }^{[12]}$ of Epo and its receptor released SUA in pigs with atherosclerotic renal artery stenosis. SUA was measured ${ }^{[13]}$ in subjects undergoing 4 months of aerobic training under the use of rhEpo. High-dose Epo and elevated SUA were considered ${ }^{[14]}$ to be aggravating factors for the prognosis of heart failure hemodialysis (HD) patients. Increased oxidative stress (OS) and inflammation but similar SUA were found ${ }^{[15]}$ in maintenance HD patients receiving Epo compared with healthy control subjects. Nephrectomy increased ${ }^{[16]}$ the SUA variably but did not change the Epo levels. Hypertensive renal vascular disease induced $^{[17]}$ or exacerbated the hyperuricemia. HD initiation ${ }^{[18]}$ augmented chronic renal failure (CRF) as a state of oxidant/ antioxidant imbalance. SUA "total antioxidant activity" and the "antioxidant gap" (in $\mathrm{mmol} / \mathrm{L}$ ) were higher in HD patients $(\mathrm{p}<0.001)$ than in control patients. However, no differences existed in SUA among uremic HD or not patients. These results suggest that HD patients appear to have hyperuricemia. Angiotensin-converting enzyme inhibitors (ACEIs) are considered ${ }^{[19]}$ to be a potential cause of inadequate Epo response in CKD patients. Valsartan, an angiotensin receptor blocker (ARB) taken at $80 \mathrm{mg} /$ day, reduced Epo levels significantly $(p=0.007)$ but did not change SUA until the 90th day in stage III-IV CKD patients. Pre-HD concentrations of SUA were significantly decreased ${ }^{[20]}$ on alternative HD by $10 \%(\mathrm{p}=0.06)$ at the end of 6 months of successive standard and alternative HDs under constant rhEpo dose values. Familial benign polycythemia (FBP) is characterized ${ }^{[21]}$ by normal SUA and usually increased Epo production. Epo doses were decreased ${ }^{[22]}$ $(\mathrm{p}<0.05)$, but the plasma SUA was kept stable by on-line HD, compared to conventional HD. Significantly higher serum Epo and SUA were found ${ }^{[23]}$ in sickle-cell $\beta$-thalassemia (S- $\beta$ thal) patients than in controls, particularly in patients with GFR $<50 \mathrm{~mL} / \mathrm{min}$. hrEpo administration ${ }^{[24]}$ to children with uremic anemia increased the SUA in the course of renal failure HD treatments. Over 12 months, $\mathrm{r}$-HuEpo treatment increased ${ }^{[25]}$ SUA significantly $(\mathrm{p}<0.01)$ in HD patients. The administration of weekly Epo via IV ${ }^{[26]}$ in HD patients revealed a significant increase of SUA. The possible effect of Epo in metabolically stable HD patients was measured ${ }^{[27]}$ by the changing ratio of postdialysis/predialysis SUA. The treatment of renal anemia with $\beta$-epoetin led ${ }^{[28]}$ to increased predialysis SUA values in chronic HD patients.

No correlation was found between Epo and SUA in 9 of the above 21 clinical examples. Epo and SUA were altered positively or negatively in the remaining 12 clinical examples (12.c.e), most of which were long-term. The study's results show a nonsignificant, slight increase in SUA, representing the deterioration of renal function by Epo administration with reperfusion time and their interaction, at least in the short-term context of 2 hours. Kidneys are also the production loci of Epo. Epo administration on ischemic kidneys may have various probable effects, e.g., a probable feedback effect on intrinsic Epo production or a probable faster reoxygenation of the ischemic kidneys. Either situation may aggravate renal function. However, it is considered safer not to draw conclusions based on such non-significant p-values. Instead, it is more meaningful to take note of the (12.c.e) same direction of Epo and SUA alterations. Renal tissue specimens were not predicted to require evaluation; thus, probable differences in the expression of apoptosis, renal function or changes in the emergence of active oxygen or neutrophils became impossible to assess. Unfortunately, the study proceeded only though the evaluation of serum biochemical findings.

Epo administration, reperfusion time, and their interaction have no significant short-term effects on SUA levels. Conclusions cannot be made based on non-significant p-values within the short time period of 2 hours. Obviously, longer study times may affirm the above (12.c.e) experience.

Ethics Committee Approval: This experimental study was approved by Veterinary Address of East Attiki Prefecture under 3693/12-11-2010 \& 14/10-1-2012 decisions.

Peer-review: Externally peer-reviewed.

Conflict of Interest: No conflict of interest was declared by the authors.

Financial Disclosure: This study was funded by Scholarship by the Experimental Research Center ELPEN Pharmaceuticals (E.R.C.E), Athens, Greece. The research facilities for this project were provided by the aforementioned institution.

\section{References}

1. Bakan V, Ciralik H, Tolun FI, Atli Y, Mil A, Oztürk S. Protective effect of erythropoietin on torsion/detorsion injury in rat model. J Pediatr Surg 2009;44:1988-94.

2. Karaca M, Odabasoglu F, Kumtepe Y, Albayrak A, Cadirci E, Keles ON. Protective effects of erythropoietin on ischemia/re- 
perfusion injury of rat ovary. Eur J Obstet Gynecol Reprod Biol 2009;144:157-62.

3. Chiquete E, Ruiz-Sandoval JL, Murillo-Bonilla LM, Arauz A, Orozco-Valera DR, Ochoa-Guzmán A, et al. Serum uric acid and outcome after acute ischemic stroke: PREMIER study. Cerebrovasc Dis 2013;35:168-74.

4. Logallo N, Naess H, Idicula TT, Brogger J, Waje-Andreassen U, Thomassen L. Serum uric acid: neuroprotection in thrombolysis. The Bergen NORSTROKE study. BMC Neurol 2011;25:114.

5. Seifert J, Frelich A, Shecterle L, St Cyr J. Assessment of Hematological and Biochemical parameters with extended D-Ribose ingestion. J Int Soc Sports Nutr 2008;15:13.

6. Hellsten-Westing Y, Kaijser L, Ekblom B, Sjödin B. Exchange of purines in human liver and skeletal muscle with short-term exhaustive exercise. Am J Physiol 1994;266:R81-6.

7. Lazzarino G, Vagnozzi R, Tavazzi B, Pastore FS, Di Pierro D, Siragusa $\mathrm{P}$, et al. MDA, oxypurines, and nucleosides relate to reperfusion in short-term incomplete cerebral ischemia in the rat. Free Radic Biol Med 1992;13:489-98.

8. Chen YR, Yang Y, Wang SC, Chiu PF, Chou WY, Lin CY, et al. Effectiveness of multidisciplinary care for chronic kidney disease in Taiwan: a 3-year prospective cohort study. Nephrol Dial Transplant 2013;28:671-82.

9. Sulikowska B, Johnson RJ, Odrowąż-Sypniewska G, Manitius J. Uric acid, renal vasoconstriction and erythropoietin relationship in IgA nephropathy revealed by dopamine-induced glomerular filtration response. Kidney Blood Press Res 2012;35:161-6.

10. De Santo NG, Perna A, Cirillo M. Low protein diets are mainstay for management of chronic kidney disease. Front Biosci (Schol Ed) 2011;1:1432-42.

11. Kmoch S, Živná M, Bleyer AJ. Familial Juvenile Hyperuricemic Nephropathy Type 2. GeneReviews ${ }^{\mathrm{TM}}$ [Internet]. Seattle (WA); University of Washington, Seattle;1993-2014.

12. Chade AR, Zhu XY, Krier JD, Jordan KL, Textor SC, Grande JP, et al. Endothelial progenitor cells homing and renal repair in experimental renovascular disease. Stem Cells 2010;28:1039-47.

13. Nunes LA, Brenzikofer R, de Macedo DV. Reference change values of blood analytes from physically active subjects. Eur J Appl Physiol 2010;110:191-8.

14. Omae K, Ogawa T, Yoshikawa M, Nitta K. The use of H1-receptor antagonists and left ventricular remodeling in patients on chronic hemodialysis. Heart Vessels 2010;25:163-9.
15. Senol E, Ersoy A, Erdinc S, Sarandol E, Yurtkuran M. Oxidative stress and ferritin levels in haemodialysis patients. Nephrol Dial Transplant 2008;23:665-72.

16. Young A, Nevis IF, Geddes C, Gill J, Boudville N, Storsley L et al. Do biochemical measures change in living kidney donors? A systematic review. Nephron Clin Pract 2007;107:c82-9.

17. Matavelli LC, Zhou X, Frohlich ED. Hypertensive renal vascular disease and cardiovascular endpoints. Curr Opin Cardiol 2006;21:305-9.

18. Mircescu G, Capuşă C, Stoian I, Vârgolici B, Barbulescu C, Ursea N. Global assessment of serum antioxidant status in hemodialysis patients. J Nephrol 2005;18:599-605.

19. Durmus A, Dogan E, Erkoc R, Sayarlioglu H, Topal C, Dilek I. Effect of valsartan on erythropoietin and hemoglobin levels in stage III-IV chronic kidney disease patients. Int J Clin Pract 2005;59:1001-4.

20. Fagugli RM, De Smet R, Buoncristiani U, Lameire N, Vanholder $\mathrm{R}$. Behavior of non-protein-bound and protein-bound uremic solutes during daily hemodialysis. Am J Kidney Dis 2002;40:339-47.

21. Vasserman NN, Karzakova LM, Tverskaya SM, Saperov VN, Muchukova OM, Pavlova GP, et al. Localization of the gene responsible for familial benign polycythemia to chromosome 11q23. Hum Hered 1999;49:129-32.

22. Maduell F, del Pozo C, Garcia H, Sanchez L, Hdez-Jaras J, Albero $\mathrm{MD}$, et al. Change from conventional haemodiafiltration to on-line haemodiafiltration. Nephrol Dial Transplant 1999;14;1202-7.

23. Katopodis KP, Elisaf MS, Pappas HA, Theodorou JC, Milionis HJ, Bourantas KL, et al. Renal abnormalities in patients with sickle cell-beta thalassemia. J Nephrol 1997;10:163-7.

24. Litwin M, Grenda R, Jelonek A. Results of treating uremia anemia with human recombinant erythropoietin. Pol Tyg Lek 1994;49:132-4.

25. Borrego FJ, Miguel JL, Zamorano A, Mu-oz J, Bajo A, LópezRevuelta K, et al. The treatment of anemia in patients on hemodialysis with recombinant human erythropoietin. Med Clin (Barc) 1991;97:687-92.

26. Tsai JC, Lai YH, Tsai ZY, Chien LJ, Tsai JH. Clinical efficacy of recombinant human erythropoietin in the treatment of anemia in hemodialysis patients: influence of dosing regimen, iron status, and serum aluminum. Gaoxiong Yi Xue Ke Xue Za Zhi 1991;7:126-35.

27. Buur T, Lundberg M. Secondary effects of erythropoietin treatment on metabolism and dialysis efficiency in stable hemodialysis patients. Clin Nephrol 1990;34:230-5.

28. Kaupke CJ, Vaziri ND, Sampson JR, Atkins K. Effect of erythropoietin therapy on diet and dialysis clearances in hemodialysis patients. Int J Artif Organs 1990;13:218-22. 